\title{
Human adjuvant disease: remission of silicone induced autoimmune disease after explantation of breast augmentation
}

\author{
W Kaiser, G Biesenbach, U Stuby, P Grafinger, J Zazgornik
}

\begin{abstract}
Autoimmune diseases following silicone or paraffin implantation are rarely encountered complications of plastic surgery. A 42 year old woman is presented who developed clinical and immunological features of systemic lupus erythematosus 11 years after silicone augmentation. After explanation antinuclear antibody titres decreased from $1 / 1280$ to $1 / 160, \mathrm{C} 4$ complement fraction and the previously raised angiotensin converting enzyme normalised in step with clinical improvement. It is important that plastic surgeons and rheumatologists should be aware of this possible association.
\end{abstract}

Although local reactions following silicone implantation have been well reported, ${ }^{1}$ little is known about systemic side effects. Acute pneumonitis, ${ }^{2}$ hypercalcaemia, ${ }^{34}$ silicone induced foreign body reactions with splenomegaly and thrombocytopenia in patients undergoing haemodialysis, ${ }^{56}$ and immune phenomena following breast augmentation have been reported. Seventy four reported cases of silicone or paraffin induced autoimmune diseases show signs and symptoms of mixed connective tissue disease, progressive scleroderma, or lupus erythematosus. ${ }^{7-18}$

We present a 42 year old woman with autoimmune phenomena following breast augmentation, and remission after explantation.

\section{Case report}

The patient, first seen in May 1986, had extrasystoles and breast pain. Both her breasts had been augmented with silicone in 1975. An additional procedure had been undertaken on the left side in 1976 to corfect a poor cosmetic result. Apart from slight contractures of both breasts and suspected silicone mastitis, the clinical findings were not remarkable. The patient had arthralgias in the region of the proximal finger joints, both shoulders, and elbow joints for some months. Furthermore, she noted an increased diffuse hair loss.

Routine laboratory tests showed normal findings for red and white blood cell counts, platelets, liver and renal functions, urine analysis, plasma fibrinogen, thyroid function tests, serum creatine kinase activity, aldolase, IgG, IgA, and calcium. Pathological findings were obtained for erythrocyte sedimentation rate $20 \mathrm{~mm} / \mathrm{h}$ (Westergren), serum albumin $34 \mathrm{~g} / 1$, IgM 7·29 $\mathrm{g} / \mathrm{l}$ (range $0.6-3.6 \mathrm{~g} / \mathrm{l}$ ), angiotensin converting enzyme $108 \mathrm{U} / \mathrm{min}$ (colorimetric assay Bühlmann, range $15-45 \mathrm{U} / \mathrm{min}$ ).
Immunological findings were as follows: $\mathrm{C} 3$ $520 \mathrm{mg} / \mathrm{l}$ (range $500-900 \mathrm{mg} / \mathrm{l}$ ), C4 $80 \mathrm{mg} / \mathrm{l}$ (range $200-400 \mathrm{mg} / \mathrm{l}$ ), rheumatoid factor (latex) negligible, $\mathrm{C}$ reactive protein negligible, antinuclear antibodies (indirect immunofluorescence method) 1/1280 of speckled pattern, DNA antibodies and extractable nuclear antigens negligible, cryoglobulins negligible, antibodies to cytoplasmic (microsomal) thyroid gland antigens $1 / 400$, antibodies to smooth muscle $1 / 10$.

Antibodies to parietal cells, mitochondria, glomerular basement membrane, and intercellular substances were negligible, anti-HIV negligible, Coombs' test (direct and indirect) negative, OKT4 72\%, and OKT8 28\%. HLAtyping was as follows: A3, A10(26), B5(51), B35, Cw4, DR2, DRw6(13).

High titres of antinuclear antibodies and consumption of the complement fraction $\mathrm{C} 4$ were confirmed during further tests. Computed tomography of the plastic mammary augmentation showed soft tissue alterations, especially near the right silicone implant. They corresponded to capsular fibrosis, and the raised angiotensin converting enzyme (108 U/min) together with the morphological findings supported the assumption of granulomatous silicone mastitis. The patient was treated symptomatically with non-steroidal anti-inflammatory drugs. After discussion the patient decided to have the breast implants removed. At follow up six months after explantation the clinical symptoms had improved, antinuclear antibodies and thyroid gland antibodies had decreased, C4 and angiotensin converting enzyme were again normal, and no circulating immune complexes were found (table 1).

\section{Discussion}

Silicone or paraffin implants used in cosmetic surgery can provoke local reactions, including fibrous and granulomatous changes, and, two to 25 years after implantation, general symptoms. Beside fibroblasts and collagen fibrils, macrophages and foreign body giant cells can also be detected histologically, and contain dimethylpolysiloxane. $^{19}$

Miyoshi was the first to note autoimmunelike diseases after intramammary injections of paraffin. ${ }^{10}$ Kumagai noted two different clinical pictures in a group of 18 cases. ${ }^{11}$ Eleven showed signs and symptoms of systemic lupus erythematosus, mixed connective tissue disease, rheumatoid arthritis, Sjögren's syndrome, or progressive systemic scleroderma. The other seven women did not completely fulfil the diagnostic 
Table 1 Immunological findings before and six months after explantation

\begin{tabular}{lll}
\hline & Before & After \\
\hline ANA* & $1 / 1280$ (speckled) & $1 / 160$ (homogeneous) \\
Thyroid antibodies & $1 / 400$ & $1 / 71$ \\
Circulating immune complexes & + & - \\
C4 (mg/l) & 80 & 230 \\
ACE $(\mathrm{U} / \mathrm{min})$ & 108 & 41 \\
IgM (g/l) & $7 \cdot 29$ & $5 \cdot 52$ \\
ESR $^{*}$ (Westergren) $(\mathrm{mm} / \mathrm{h})$ & 20 & 9
\end{tabular}

*ANA=antinuclear antibodies; $\mathrm{ACE}=$ angiotensin converting enzyme; $\mathrm{ESR}=$ erythrocyte sedimentation rate.

Table 2 Influence of explantation or mastectomy on the clinical course in patients with human adjuvant disease

\begin{tabular}{|c|c|c|c|}
\hline $\begin{array}{l}\text { Reference and } \\
\text { number of patients }\end{array}$ & $\begin{array}{l}\text { Technique of } \\
\text { augmentation }\end{array}$ & $\begin{array}{l}\text { Diagnosis and } \\
\text { symptoms }\end{array}$ & Clinical course \\
\hline $\begin{array}{l}\text { Miyoshi }(1964)^{10} \\
(n=2) \\
\text { Yoshida }(1973)^{16} \\
(n=7) \\
\text { Baldwin }(1983)^{8} \\
(n=1) \\
\text { Kumagai }(1984)^{11} \\
(n=3) \\
\text { Sergott }(1986)^{13} \\
(n=1) \\
\text { Spiera }(1988)^{14} \\
(n=1) \\
\text { Varga }(1989)^{18} \\
(n=2) \\
\text { Our patient }\end{array}$ & $\begin{array}{l}\text { Paraffin injections } \\
\text { Paraffin injections } \\
\text { Saline filled silicone } \\
\text { implants } \\
\text { Paraffin injections } \\
\text { Silicone injections } \\
\text { Silicone implants } \\
\text { Silicone implants } \\
\text { Silicone implants }\end{array}$ & $\begin{array}{l}\text { Hypergammaglobulin- } \\
\text { aemia } \\
\text { Adjuvant polyarthritis } \\
\text { Human adjuvant } \\
\text { disease } \\
\text { Scleroderma } \\
\text { Arthralgias, iritis } \\
\text { Scleroderma } \\
\text { Scleroderma } \\
\text { Human adjuvant } \\
\text { disease }\end{array}$ & $\begin{array}{l}\text { Both improved } \\
\text { Four patients improved, } \\
\text { no effect in three cases } \\
\text { Improved } \\
\text { No effect in all three cases } \\
\text { Slightly improved } \\
\text { Improved } \\
\text { No effect in both cases } \\
\text { Improved }\end{array}$ \\
\hline
\end{tabular}

criteria of the American Rheumatism Association, but were classified without rigorous diagnosis as a group with 'human adjuvant disease' on the basis of experimental studies by Stoerk ${ }^{20}$ and Pearson. ${ }^{21}$ These authors had been able to induce polyarthritis in rats with one single subcutaneous injection of heat inactivated tubercle bacilli in oil emulsion ('Freund's complete adjuvant'). No hypersensitivity was seen after injection of either the micro-organism alone or the carrier medium. This adjuvant effect of inducing enhancement of humoral response has been shown for a number of substances, including silicone dioxide. ${ }^{22}$ Thus reports implicating quartz as a cause of progressive scleroderma ${ }^{23}$ are noteworthy.

To our knowledge only five HLA serotypings including the DR locus have been done in patients with human adjuvant disease. $91213 \quad 15$ Therefore it is not possible to define the prospective risk of silicone induced autoimmune phenomena. A manifest autoimmune disease should be regarded as a contraindication for plastic augmentation surgery. In our case serological autoimmune phenomena were shown 11 years after silicone augmentation. The high titre of antinuclear antibodies of speckled pattern was accompanied by consumption of complement fraction $\mathrm{C} 4$. These findings enable the diagnosis of collagen disease. In addition, autoantibodies to thyroid gland antigens were found. Four cases of Hashimoto thyroiditis after silicone implantation are known.

The effect of explantation on the clinical course is not clear, but in some cases removal led to clinical improvement (table 2). There are insufficient data at present to justify the routine removal of breast prosthesis in each case of possible association. In our case removal of the prosthesis produced an impressive effect both on clinical signs and on immunological findings.

In view of these reports patients must be warned before augmentation. It is possible to induce systemic disease by cosmetic surgery implants. Follow up examinations should not be confined to local reactions. Some years after implantation a brief immunological screening should be performed, including determination of rheumatoid factor, antinuclear antibodies, C3 and $\mathrm{C} 4$ complement fractions, and quantitative immunoglobulins.

We thank Professor G Wick, Institute for General and Experimental Pathology of the University of Innsbruck, for performing the immunological investigations.

1 Asplund O. Capsular contracture in silicone gel and saline filled breasts implants after reconstruction. Plast Reconstr Surg 1984; 73: 270-4

2 Chastre J, Basset F, Viau F, et al. Acute pneumonitis after subcutaneous injections of silicone in transsexual men. N Engl F Med 1983; 308: 764-7.

3 Kozeny G A, Barbato A L, Bansal V K, Vertuno L L, Hano J E. Hypercalcemia associated with silicone-induced granulomas. N Engl f Med 1984; 311: 1103-5.

4 Altmann P, Dodd S, Williams A, Marsh F, Cunningham J. Silicone induced hypercalcemia in hemodialysis patients. Nephrology Dialysis and Transplantation 1987; 2: 26-9.

5 Bommer J, Ritz E, Waldherr R, Gastner M. Silicone cell inclusions causing multiorgan foreign body reaction in inclusions causing multiorgan foreign bod

6 Bommer J, Ritz E, Waldherr R. Silicone induced splenomegaly. N Engl fु Med 1981; 305: 1077-9.

7 Byron M A, Venning V A, Mowat A G. Post mammoplasty human adjuvant disease. Br F R heumatol 1984; 23: 227-8.

8 Baldwin C M, Kaplan E N. Silicon-induced human adjuvant disease? Ann Plast Surg 1983; 10: 270-3.

9 Fock K M, Feng $\mathrm{P}$ H, Tey B. Autoimmune disease developing after augmentation mammoplasty: report of 3 cases. F R heumatol 1984; 11: 98-100.

10 Miyoshi K, Miyaoka T, Kobayashi Y, et al. Hypergammaglobulinemia by prolonged adjuvanticity in man: disorders developed after augmentation mammoplasty. Ijishimpo 1964; 2122: 9-14.

11 Kumagai Y, Shiokawa Y, Medsger T A Jr, Rodnan G P. Clinical spectrum of connective tissue disease after cosmetic clinical spectrum of connective tissue diseas

12 Okano V, Nishikai M, Sato A. Scleroderma, primary biliary cirrhosis and Sjögren's syndrome after cosmetic breast augmentation with siliçone injection: a case report of possible human adjuvant disease. Ann Rheum Dis 1984; 43: 520-1.

13 Sergott T J, Limoli J P, Baldwin C M Jr, Laub D R. Human adjuvant disease, possible autoimmune disease after silicone implantation: a review of the literature, case studies, and speculation for the future. Plast Reconstr Surg 1986; 78: $104-14$.

14 Spiera $\mathrm{H}$. Scleroderma after silicone augmentation mammoplasty. JAMA 1988; 260: 236-8.

15 van Nunen S A, Gatenby P A, Basten A. Post-mammoplasty connective tissue disease. Arthritis Rheum 1982; 25: 694-7.

16 Yoshida K. Post mammoplasty disorder as an adjuvant disease of man. Shikoku Acta Med 1973; 29: 318-32.

17 Endo L P, Edwards N L, Longley S, Cormann L C, Panush R S. Silicone and rheumatic diseases. Semin Arthritis Rheum R S. Silicone and

18 Varga J, Schumacher H R, Jimenez S A. Systemic sclerosis after augmentation mammoplasty with silicone implants. Ann Intern Med 1989; 111: 377-83.

19 Domanskis E J, Owsley J. Histological investigations into the etiology of capsular contracture following augmentation mammoplasty. Plast Reconstr Surg 1976; 58: 689-93.

20 Stoerk H C, Bielinsky T C, Budzilovich T. Chronic polyarthritis in rats injected with spleen in adjuvants. $A m \mathcal{F}$ Pathol 1954; 30: 616.

21 Pearson C M. Development of arthritis, periarthritis, periostitis in rats given adjuvants. Proc Soc Exp Biol Med 1956; 91: 95-101.

22 Pernis P, Paronetto F. Adjuvant effect of silica (tridynite) on antibody production. Proc Soc Exp Biol Med 1980; 110: $390-2$.

23 Ziegler V, Pampel W, Zschunke E, Münzberger H, Mährlein W, Köppenig H. Kristalliner Quarz, (eine) Ursache der progressiven Sklerodermie? Dermatol Monatsschr 1982; 168 398-401. 